\title{
PENGARUH INTEGRASI PENDIDIKAN KARAKTER DALAM PEMBELAJARAN IPS TERHADAP KETERAMPILAN SOSIAL SISWA SD NEGERI 3 KABUPATEN SORONG
}

\author{
Hilda Wulandari ${ }^{1}$, Mursalim ${ }^{2}$ \& Ihsan $^{3}$ \\ Program Studi Pendidikan Guru Sekolah Dasar, Universitas Pendidikan Muhammadiyah \\ Sorong \\ hildawulandari1904@gmail.com
}

\begin{abstract}
Abstrak
Penelitian ini bertujuan untuk mengetahui pengaruh integrasi pendidikan karakter dalam pembelajaran IPS terhadap keterampilan sosial siswa kelas V di SD Negeri 3 Kabupaten Sorong. Jenis penelitian ini adalah penelitian kuantitatif dengan metode eksperimen. Teknik pengumpulan data menggunakan angket, observasi dan dokumentasi. Uji analisis data yang digunakan analisis uji normalitas dan uji hipotesis. Berdasarkan hasil uji reliabilitas angket pendidikan karakter diperoleh hasil Cronbach's Alpha sebesar 0,703 da n uji reliabilitas angket keterampilan sosial diperoleh hasil Cronbach's Alpha sebesar 0,698. Dari analisis data diperoleh uji normalitas kolmogrov smirnov pendidikan karakter Asymp. Sig (2-tailed) 0,071 >0,05 dan keterampilan sosial Asymp. Sig (2-tailed) $0,198>0,05$ maka diperoleh data normal. Hasil analisis regresi linier sederhana untuk mengetahui pengaruh antara pendidikan karakter terhadap keterampilan sosial siswa menunjukkan pengaruh dilihat dari nilai koefisien korelasi sebesar $68,6 \%$. Artinya bahwa variabel keterampilan sosial Y dipengaruhi sebesar $68,6 \%$ oleh pendidikan karakter $\mathrm{X}$ sedangkan sisanya $31,4 \%$ dipengaruhi faktorfaktor yang lain. Dan diperoleh $F_{\text {tabel }}$ sebesar 4,20 pada taraf $5 \% . H_{0}$ ditolak apabila $F_{\text {hitung }}>F_{\text {tabel. }}$ Karena $\mathrm{F}_{\text {hitung }}=24,917$ dan lebih besar dari $\mathrm{F}_{\text {tabel }} 4,20$ maka $\mathrm{H}_{0}$ ditolak dan $\mathrm{H}_{1}$ diterima. Sehingga dapat disimpulkan bahwa terdapat pengaruh yang signifikan antara pendidikan karakter terhadap keterampilan sosial siswa.
\end{abstract}

Kata Kunci : Pendidikan karakter, IPS, Keterampilan Sosial. 


\section{PENDAHULUAN}

Pendidikan menjadi salah satu tempat yang dapat membantu guru dalam membentuk karakter seorang siswa. Karakter adalah nilai-nilai baik yang dimiliki seseorang. Sehingga dapat disimpulkan bahwa seseorang yang berkarakter jika seseorang tersebut menerapkan nilai-nilai yang baik didalam kehidupan sehari-hari. Pendidikan karakter juga merupakan gerakan nasional yang dapat mewujudkan sekolah agar dapat membentuk generasi muda bangsa yang memiliki etika, disiplin, bertanggung jawab, religius, jujur. Pendidikan karakter bertujuan membentuk pribadi seseorang dalam bermasyarakat dan bernegara menjadi baik, sehingga generasi muda tersebut mampu mengantisipasi yang terjadi di masa datang (Afandi, 2011). Pendidikan karakter juga memiliki tujuan agar siswa memiliki pengetahuan untuk mengkaji dan mempersonalisasi nilai serta mengembangkan keterampilan sosial yang dapat membuat akhlak siswa bisa berkembang dan semakin tumbuh (Rasyid \& Hasyim, 2016).

Karakter yang akan diterapkan oleh peneliti yaitu religius (taat menjalankan ajaran agama), jujur (bisa dipercaya), dan disiplin (patuh dan tertib). Pendidikan karakter menjadi salah satu sistem yang wajib menanamkan kepada siswa nilai nilai baik terhadap sesama makhluk dan terhadap Tuhan Yang Maha Esa. Demikian pendidikan karakter memiliki tujuan untuk dapat meningkatkan kualitas, mutu dan hasil pendidikan para siswa mengarah pada pencapaian karakter dan akhlak siswa secara seimbang. Pendidikan karakter sangat diutamakan agar masyarakat tidak memandang seseorang berdasarkan tingginya pendidikan yang telah diraih saja melainkan lebih mengutamakan karakter yang dimiliki setiap individu.

Persoalan karakter menjadi
pembahasan utama didalam dunia
pendidikan dengan keadaan krisis moral
sekarang ini. Sebagai calon guru harus
menyadari tanggung jawab pendidik untuk

memperhatikan anak didiknya terutama karakter masing-masing dengan tujuan membentuk penyempurnaan hidup dan melatih kemampuan seseorang menuju arah hidup lebih baik. Pendidikan dibangku sekolah dasar (SD) merupakan jenjang pertama sebelum menuju jenjang yang lebih tinggi lagi dan dapat diibaratkan sebagai tiket masuk menuju sebuah tempat. Jika terjadi kegagalan pada tahap ini dalam pembinaan karakter dapat berdampak buruk pada jenjang selanjutnya. Pendidikan di sekolah dasar dapat digunakan dalam untuk menekan pada pembinaan watak, karakter dan kepribadian para siswa.

Oleh karena itu ketiga hal tersebut harus ditanamkan dengan baik untuk dijadikan sebagai bekal dalam menghadapi tantangan kedepan yang semakin berat. Adanya penerapan pendidikan karakter dirasa sangat penting ketika mulai muncul berbagai bentuk penyimpangan sosial dan asusila yang terjadi dikehidupan sekarang. Hampir setiap tayangan televisi dan sosial media menayangkan yang berkaitan tentang semakin rendahnya karakter setiap orang sekarang ini dan semakin rendahnya mutu pendidikan. Hal-hal tersebut tentu sangat membuat orangtua dan pihak lembaga pendidikan merasa khawatir dan cemas menghadapi hal tersebut.

Pembelajaran IPS adalah program pendidikan dan bidang pengetahuan yang menyajikan pengetahuan sosial dan membina siswa agar dapat menjadi warga dan masyarakat yang memiliki tanggung jawab (Afandi, 2011). Pembelajaran IPS adalah ilmu yang mengembangkan pengetahuan, nilai, sikap, dan keterampilan sosial siswa sehingga siswa dapat menelaah dan menghadapi kehidupan sosial yang akan dihadapi (Rasyid \& Hasyim, 2016). Sehingga diharapkan integrasi pendidikan karakter yang diterapkan dalam pembelajaran IPS dapat membentuk pribadi seorang anak agar menjadi warga dan masyarakat yang baik agar dapat mengantisipasi gejala moral sekarang ini. 
Berhubungan dengan permasalahan di atas, maka upaya meningkatkan karakter siswa di SD Negeri 3 Kabupaten Sorong dalam pembelajaran IPS dilakukan membantu meningkatkan karakter terutama religius, jujur, dan disiplin. Pada dasarnya penanaman IPS sudah melekat dengan adanya keterpaduan ilmu-ilmu sosial yang memiliki tujuan untuk meningkatkan kepekaan dan keterampilan sosial dalam memecahkan masalah-masalah sosial. Keterampilan sosial adalah sebuah keterampilan yang dapat diperoleh melalui proses belajar tentang cara untuk mengatasi dan melakukan hubungan sosial dengan baik (Barat, 2018).

Sebagai hasil pengamatan (observasi) di SD Negeri 3 Kabupaten Sorong kelas V bertepatan dengan tempat magang III angkatan III peneliti yang dilaksanakan pada tanggal 3 september sampai dengan 3 oktober 2018. Disekolah ini dikelas V banyak terdapat para siswa yang memiliki kurangnya disiplin terhadap aturan sekolah, kurangnya sopan santun kepada teman bahkan kepada guru, kurangnya rasa hormat kepada guru yang menjadi orangtua yang mengawasi mereka disekolah, penggunaan bahasa yang kasar dan tidak teratur, memanggil yang lebih tua dengan seenaknya, kejujuran yang dimiliki para siswa pun semakin hari semakin lenyap, para siswa sekarang identik bergaul dengan mengelompok-mengelompok (geng) dan kurang kesopanan terhadap guru contohnya ketika berpapasan dengan guru siswa tersebut menunduk, tidak mengucap salam atau bahkan pura-pura tidak mengenalinya.

Perbuatan-perbuatan tersebut tidak seharusnya ada dan tidak seharusnya dilakukan oleh siswa dengan usia mereka yang belum cukup karena pada dasarnya karakter anak SD lebih ingin tahu tentang bermain dan ingin belajar. Hal tersebut terjadi karena kurangnya penanaman pendidikan karakter didalam diri siswa. Perubahan-perubahan yang terjadi pada karakter anak-anak sekarang ini sangat disayangkan, dengan usia dan statusnya sebagai anak SD tidak diwajarkan memiliki karakter tersebut sama halnya hal tersebut menjadi landasan untuk anak-anak tumbuh dan berkembang. Kesalahan dalam penanaman karakter siswa tersebut dapat berakibat fatal pada masa depan yang akan dijalani nantinya. Hal tersebut menjadi masalah yang harus dipikirkan oleh guru dan orang tua. Tak bisa dipungkiri waktu siswa dirumah lebih banyak dibanding waktu disekolah sehingga tak menutup kemungkinan kebiasaan buruk dirumah dibawa siswa ke sekolahnya.

Sebagai calon guru nantinya peneliti pun mulai merasa khawatir dan gelisah melihat peristiwa tersebut terjadi disekolah tempat magang III peneliti. Kekhawatiran tersebut menimbulkan pertanyaan kenapa anak-anak tersebut begitu cepat terpengaruh dan kenapa orangtua begitu menganggap remeh hal tersebut yang ternyata suatu saat nanti akan menjadi dampak yang sangat fatal nantinya. Hal ini menjadi masalah serius karena pada kelas $\mathrm{V}$ dengan usia 11 tahun dimana usia tersebut sangat rentan dan merupakan usia awal remaja pencari jati diri. Menyelesaikan masalah tersebut peneliti mencoba memberikan solusi yaitu dengan melihat adanya pengaruh integrasi pendidikan karakter dalam pembelajaran IPS terhadap keterampilan sosial siswa. Dengan cara memasukkan nilai-nilai pendidikan karakter dalam pembelajaran IPS dapat meningkatkan keterampilan sosial yang dimiliki para siswa.

Harapannya dengan diterapkan pendidikan karakter disekolah dapat membentuk keterampilan sosial para siswa menjadi beretika, bermoral, lebih disiplin, sopan dan santun sehingga mampu membawa diri ketika berinteraksi dengan masyarakat. Karena sekolah bukan hanya sebagai tempat mengajarkan dan mementingkan aspek kognitifnya, tetapi mengajarkan bagaimana etika-etika baik yang harus dilakukan, bagaimana cara bersifat kepada guru, orangtua dan masyarakat dilingkungan hidup. Diharapkan dengan diterapkannya pendidikan karakter di 
sekolah tersebut dapat meningkatkan semua potensi kecerdasan anak-anak yang dilandasi oleh karakter sehingga menjadikan generasi penerus yang harus berpegang teguh pada karakter yang beradab.

Berdasarkan rumusan latar belakang di atas, maka penelitian ini memiliki tujuan yaitu untuk mengetahui pengaruh integrasi pendidikan karakter dalam pembelajaran IPS terhadap keterampilan sosial siswa kelas V di SD Negeri 3 Kabupaten Sorong.

\section{Kajian Pustaka dan pengembangan hipotesis}

\section{Pendidikan Karakter}

Dalam Undang-undang nomor 20 tahun 2003 tentang Sistem Pendidikan Nasional pada pasal satu antara lain disebutkan bahwa pendidikan adalah suatu usaha sadar terencana untuk mewujudkan suasana belajar dan proses pembelajaran agar siswa secara aktif mengembangkan potensi dirinya untuk memiliki kekuatan spiritual keagamaan, akhlak mulia, kecerdasan, kepribadian, pengendalian diri, dan keterampilan yang diperlukan dirinya, masyarakat, bangsa dan negara (Mulyatiningsih, 2010).

Kemudian terdapat istilah yang lain bahwa karakter adalah personality characteristic yang berarti yaitu bakat, kemampuan, sifat yang secara konsisten diperagakan oleh seseorang termasuk sifatsifat fisik, ciri-ciri kepribadian dan pola-pola perilaku seseorang (Anshor, 2014). Karakter merupakan cara berpikir dalam berperilaku yang dimiliki oleh seseorang sehingga menjadi ciri khas setiap individu agar hidup dan bekerja sama di dalam keluarga masyarakat maupun negara. Individu yang memiliki karakter baik adalah individu yang dapat mengambil keputusan dan mampu mempertanggungjawabkan semua akibat dari keputusan tersebut (Setiawan, 2013).

Pendidikan karakter digambarkan sebagai suatu kurikulum yang dikembangkan secara khusus untuk mengajar anak-anak tentang kualitas dan sifat-sifat karakter yang baik. Salah satu caranya yaitu anak-anak dapat mempelajari tentang karakter yang baik adalah melalui halaman-halaman literatur anak berkualitas tinggi (Almerico, 2014).

Pendidikan karakter mengangkat nilai-nilai universal yang dapat diterima oleh latar belakang agama, budaya dan tradisi yang berbeda, tidak sekedar mengangkat teori semata namun juga aplikasinya di masyarakat (Rasyid \& Hasyim, 2016).

Pendidikan karakter merupakan perilaku yang semakin berkembang, berupaya secara optimal untuk mendorong perkembangan motivasi dan kompetensi etis dan pro-sosial siswa. Pendidikan karakter menjadi komponen pertama untuk dapat berkualitas dan menjadi peluang bagi siswa agar memiliki pendidikan yang berbakat (Berkowitz \& Hoppe, 2009).

Menurut pengertian beberapa pendapat diatas peneliti dapat menyimpulkan bahwa pendidikan karakter adalah usaha terencana guru yang dilakukan untuk menanamkan nilai-nilai karakter agar para siswa memiliki sikap, perilaku, etika dan moral sesuai dengan nilai yang ditanamkan serta tindakan dan kemauan melakukan baik terhadap Tuhan Yang Maha Esa, maupun terhadap sesama manusia.

\section{Pembelajaran IPS (Ilmu Pengetahuan Sosial) di Sekolah Dasar}

Pendidikan IPS disekolah dasar pada prinsipnya tidak hanya mengajarkan ilmuilmu sosial menjadi disiplin ilmu, melainkan mengajarkan konsep-konsep esensi ilmuilmu sosial agar dapat membentuk siswa menjadi warga negara yang baik (good citizen). Pada kelas rendah program pendidikan IPS dilakukan dengan cara mengintegrasikan beberapa disiplin yang bertolak dari suatu tema tertentu dan juga melibatkan disiplin sejarah, sains dan bahasa. Sedangkan program pendidikan IPS untuk kelas-kelas tinggi disajikan secara terpadu (Anshor, 2014).

Menurut Rudy Gunawan (2011), menyatakan bahwa IPS adalah salah satu mata pelajaran yang diberikan di bangku sekolah dasar yang berfungsi untuk mengkaji 
sekumpulan peristiwa, konsep, fakta, dan generalisasi yang memiliki kaitan dengan isu-isu sosial (Putra, 2015). IPS merupakan salah satu mata pelajaran yang mempunyai peranan besar sebagai salah satu disiplin ilmu yang bertujuan untuk mendidik siswa menjadi warga negara yang bertanggung jawab (Ramdani \& Zamroni, 2014).

Dari semua sumber di atas dapat di tarik kesimpulan bahwa Ilmu Pengetahuan Sosial sebenarnya di dasari oleh banyak cabang-cabang ilmu sosial yang mempunyai fungsi dan tujuan yang pada inti nya sama yaitu untuk hidup bermasyarakat dengan baik.

\section{Keterampilan Sosial (Social Skill)}

Keterampilan sosial adalah suatu kemampuan yang dimiliki sese- orang untuk mampu bergaul, bekerja sama dengan orang lain baik individu maupun kelompok secara baik, sehingga terjalin ikatan nonfisik dalam masyarakat (Amtorunajah, 2015).

Keterampilan sosial adalah keterampilan yang memungkinkan orang untuk berkomunikasi, belajar, mengajukan pertanyaan, meminta bantuan, mendapatkan kebutuhan mereka dengan cara yang sesuai, bergaul dengan orang lain, mencari teman dan mengembangkan hubungan antar individu yang sehat, melindungi diri mereka sendiri, dan umumnya dapat berinteraksi dengan siapa pun dan semua orang yang mereka temui di perjalanan kehidupan mereka (Tyas Martika Anggriana, Asroful Kadafi, 2017)

Keterampilan sosial (social skill) adalah sebuah konsep yang sangat sulit dipahami. Dalam menemukan definisi serta pendekatan untuk keterampilan sosial, harus mempertimbangkan bagaimana nilai dari suatu keterampilan tertentu dan oleh siapa penilainya (Widyastuti, 2011).

Keterampilan sosial merupakan suatu keahlian dalam bergaul dengan orang lain di sekelilingnya (Suardi, 2013). Kemudian Surya (2013), berpendapat keterampilan sosial juga diartikan sebagai sebuah perilaku tertentu yang menjadi dasar dalam tercapainya interaksi sosial secara efektif disebut keterampilan sosial (Yudiastuti, 2015).

Dari pendapat para ahli di atas dapat dipahami bahwa semakin bertambah usia seseorang maka mereka semakin pula memerlukan orang lain. Karena sebenarnya manusia adalah makhluk sosial yang artinya manusia tersebut tidak bisa hidup sendiri di lingkungan nya tanpa berinteraksi dengan manusia lain nya. Sehingga peneliti menyimpulkan bahwa keterampilan sosial adalah suatu cara seseorang dalam melakukan interaksi dilihat dari bentuk perilaku dan komunikasi yang digunakan tersebut.

\section{Penelitian Terdahulu}

a. Hasil penelitian yang relevan sebelumnya adalah penelitian yang dilakukan oleh Amanatus Shobroh (2015), tentang pengaruh pendidikan karakter terhadap pembentukan kejujuran siswa MTS Negeri Galur Kulon Progo Yogyakarta.

b. Hasil penelitian yang relevan sebelumnya adalah penelitan yang dilakukan oleh Yatmini (2016) tentang integrasi pendidikan karakter dalam pembelajaran IPS untuk pengalaman nilai kedisiplinan siswa SMP Negeri 25 Semarang.

c. Hasil penelitian yang relevan sebelumnya adalah penelitan yang dilakukan oleh Wildan Pratama Siahaan (2017), tentang pengaruh lingkungan sekolah terhadap pembentukan karakter siswa di MAS Miftahussalam Kecamatan Medan Petisah Tahun Ajaran 2016/2017.

\section{METODOLOGI}

Jenis penelitian ini adalah penelitian kuantitatif dengan metode eksperimen. Penelitian ini digunakan untuk menguji pengaruh variabel bebas (pendidikan karakter) dan variabel terikat (keterampilan sosial). Untuk menganalisis variabel menggunakan teknik regresi linear sederhana. Alasan dipilihnya jenis penelitian ini karena peneliti ingin mengetahui seberapa 
besar pengaruh integrasi pendidikan karakter dalam pembelajaran IPS terhadap keterampilan sosial. Penelitian ini terdiri dari dua variabel yaitu variabel bebas $(\mathrm{X})$ yaitu integrasi pendidikan karakter dan variabel terikat (Y) yaitu keterampilan sosial.

Populasi dalam penelitian adalah seluruh siswa kelas $\mathrm{V}$ di SD Negeri 3 Kabupaten Sorong. Adapun sampel dalam penelitian ini berjumlah 30 orang. Teknik pengambilan sampel dilakukan menggunakan teknik sampling jenuh. Teknik pengumpulan data menggunakan beberapa metode yaitu sebagai berikut :
a) Angket
b) Observasi
c) Dokumentasi

\section{Uji Prasyarat Analisis}

\section{a) Uji Validitas}

Validitas instrumen dilakukan dengan cara professional judgment yang artinya melalui satu dosen PKn yang mengerti dan memahami serta meminta pertimbangan mengenai angket yang diberikan kepada siswa.

b) Uji Reliabilitas

Kriteria suatu instrumen dikatakan reliabel apalbila $\left(\mathrm{r}_{11)}>0,6\right.$. Uji reliabilitas menggunakan SPSS 16.

c) Uji Normalitas

Untuk menguji apakah distribusi normal atau tidak dengan melakukan pengujian Kolmogorov Smirnov menggunakan SPSS 16.

d) Uji Hipotesis

\section{Uji Regresi Sederhana}

Untuk mengetahui sejauh mana pengaruh pendidikan karakter terhadap keterampilan sosial menggunakan rumus sebagai berikut :

$$
Y=a+b X
$$

Keterangan :

$\mathrm{X}=$ Pendidikan karakter

$\mathrm{Y}=$ Keterampilan sosial

$a=$ intersep (konstanta regresi)

$\mathrm{b}=$ koefisien regresi

\section{HASIL DAN PEMBAHASAN}

4.1 Hasil

a) Uji Validitas

Penelitian ini menggunakan instrumen penelitian berupa angket berjumlah 26 butir pernyataan. Sebelum angket diberikan kepada siswa di sekolah, terlebih dahulu dikonsultasikan dengan satu professional judgment dosen PKn Unimuda Sorong dengan cara dimintai pendapat tentang instrumen angket yang telah disusun oleh peneliti. Ahli tersebut menyatakan bahwa instrumen angket yang telah dibuat tersebut telah layak digunakan.

\section{b) Uji reliabilitas}

Uji reliabilitas digunakan untuk mengetahui apakah butir angket yang diujikan reliabel dalam memberikan pengukuran terhadap siswa. Untuk menguji reliabilitas instrumen peneliti menggunakan SPSS v16. Berikut ini adalah hasil uji reliabilitas :

Tabel 4.3 Uji realibiltas angket pendidikan karakter Reliability Statistics

\begin{tabular}{l|l}
\hline Cronbach's alpha & N of items \\
\hline .703 & 27 \\
\hline
\end{tabular}

Sumber : SPSS V16 statistic for windows

Berdasarkan perhitungan uji reliabilitas terhadap instrumen angket pendidikan karakter menggunakan SPSS 16 diperoleh hasil Cronbach's Alpha untuk instumen angket pendidikan karakter sebesar 0,703. Dengan demikian, instrumen angket pendidikan karakter tersebut telah memenui syarat reliabel.

Tabel 4.4 Uji realibiltas angket keterampilan sosial Reliability Statistics

\begin{tabular}{l|l}
\hline Cronbach's alpha & Nof items \\
\hline .698 & 27 \\
\hline
\end{tabular}

Sumber: SPSS V16 statistic for windows

Berdasarkan perhitungan uji reliabilitas terhadap instrumen angket keterampilan sosial menggunakan SPSS v16 
diperoleh hasil Cronbach's Alpha untuk instumen angket sebesar 0,698. Dengan demikian, instrumen angket keterampilan sosial tersebut telah memenui syarat reliabel.

\section{c) Uji Normalitas}

Berdasarkan pengujian Kolmogorov Smirnov didapatkan data sebagai berikut :

Tabel 4.8 Hasil uji kolmogrov smirnov

\begin{tabular}{lc|r}
\hline & & \multicolumn{2}{|l}{$\begin{array}{l}\text { Pendidikan } \\
\text { karakter }\end{array}$} \\
\hline $\mathrm{N}$ & & 30 \\
Normal Parameters $^{\mathrm{a}}$ & Mean & 81.63 \\
& Std. Deviation & 7.828 \\
Most Extreme Differences & Absolute & .236 \\
& Positive & .141 \\
& Negative & -.236 \\
Kolmogorov-Smirnov Z & & 1.292 \\
Asymp. Sig. (2-tailed) & & .071 \\
\hline a. Test distribution is Normal. & \\
\hline
\end{tabular}

Sumber : SPSS V16 statistic for windows

Diperoleh data hasil pengujian normalitas di atas didapatkan nilai Kolmogorov Smirnov $Z$ dengan nilai $\mathrm{p}$ atau Asymp. Sig (2-tailed). Kemudian nilai dibandingkan dengan 0,05 (taraf signifikan $5 \%$ ) untuk mengambil keputusan dengan kriteria sebagai berikut :

Jika Asymp. Sig (2-tailed) $<0,05$ maka distribusi data tidak normal.

Jika Asymp. Sig (2-tailed) > 0,05 maka distribusi data normal.

Tabel 4.9 Keputusan kriteria uji normalitas

\begin{tabular}{l|l|l|l}
\hline Nama variabel & $\begin{array}{c}\text { Asymp. } \\
\text { Sig (2- } \\
\text { tailed) }\end{array}$ & $\begin{array}{c}\text { Taraf } \\
\text { signifikan }\end{array}$ & Keputusan \\
\hline $\begin{array}{l}\text { Pendidikan } \\
\text { Karakter }\end{array}$ & 0.071 & 0,05 & Normal \\
$\begin{array}{l}\text { Keterampilan } \\
\text { Sosial }\end{array}$ & 0.198 & 0,05 & Normal \\
\hline
\end{tabular}

\section{d) Uji Hipotesis}

\section{Uji Analisis Regresi Sederhana}

Berdasarkan perhitungan analisis secara cermat, maka didapat hasil interpretasi data sebagai berikut :

a) Interprestasi persamaan regresi
Dari hasil perhitungan diperoleh nilai koefisien penduga intersap $(\alpha)$ sebesar 48,57 dan nilai koefisien intersap persamaan regresi (b) sebesar 0,399. Sehingga dapat diperoleh persamaan regresi sederhana adalah:

$$
\mathrm{Y}=48,57+0,399 \mathrm{X}
$$

Dari persamaan regresi dapat diketahui bahwa jika tidak ada perlakuan apa pun yang diberikan kepada siswa, keterampilan sosial siswa adalah 48,57. Jika pendidikan karakter meningkat 1,00 poin, maka keterampilan sosial siswa adalah 48,57 akan meningkat sebesar 0,399 .

b) Koefisien Korelasi (r)

Dari perhitungan secara manual koefisien korelasi didapatkan nilai $r_{\text {hitung }}$ sebesar 0,686 Pada $r_{\text {tabel }}$ sebesar 0,361 dengan taraf signifikansi $5 \%$. Dapat disimpulkan bahwa terdapat korelasi yang kuat antara pendidikan karakter terhadap keterampilan sosial siswa.

c) Koefisien Determinasi (D)

Nilai koefisien determinasi dalam penelitian ini adalah $\mathrm{r}^{2}=$ 0,470 . Koefisien determinasi menunjukkan bahwa sebesar $\mathrm{D}=$ 47,0 \% keterampilan sosial siswa dipengaruhi oleh faktor pendidikan karakter yang terdiri dari beberapa indikator yaitu religius, jujur, toleransi, disiplin, kerja keras dan kreatif dalam pembelajaran dan lingkungan sekitar.

d) Uji Signifikansi

Dari perhitungan $F_{\text {tabel }}$, maka dapat diperoleh $F_{\text {tabel }}$ sebesar 4,20 pada taraf $5 \% . \mathrm{H}_{0}$ ditolak apabila $\quad F_{\text {hitung }}>\quad F_{\text {tabel. }}$ Karena $\mathrm{F}_{\text {hitung }}=24,917$ dan lebih besar dari $\mathrm{F}_{\text {tabel }}$ 4,20 maka $\mathrm{H}_{0}$ ditolak 


\subsection{Pembahasan}

dan $\mathrm{H}_{1}$ diterima. Sehingga dapat disimpulkan bahwa terdapat pengaruh yang signifikan antara pendidikan karakter terhadap keterampilan sosial siswa.

\subsubsection{Pendidikan Karakter}

Pada penelitian ini, penulis memberikan angket karakter kepada masing-masing siswa. Penulis memberikan angket yang terdiri dari 26 butir yang terdiri dari 13 pernyataan positif dan 13 negatif. Penyebaran angket bertujuan untuk mengetahui seberapa besar pengaruh integrasi pendidikan karakter dalam pembelajaran IPS terhadap keterampilan sosial siswa. Angket pendidikan karakter berisi pernyataan-pernyataan yang dikembangkan dari indikator-indikator yang telah ditentukan antara lain religius, jujur, toleransi, disiplin, kerja keras dan kreatif dalam pembelajaran dan lingkungan sekitar.

Pada hasil penelitian dan analisis data pendidikan karakter diperoleh dari 30 siswa kelas V 29 siswa yang memiliki persentase $96 \%$ dengan kriteria cukup baik, 1 siswa memiliki presentase $4 \%$ dengan kriteria kurang baik. Hasil perhitungan diperoleh rata-rata total 3,01 yang berada pada kategori cukup baik. Hal ini dikarenakan pada saat kegiatan belajar mengajar berlangsung siswa sangat antusias dan memerhatikan materi yang diajarkan yang berkaitan dengan pendidikan karakter.

Kesuma (2012), menuliskan bahwa pendidikan karakter merupakan sebuah proses transformasi nilai-nilai kehidupan agar ditumbuhkembangkan dalam kepribadian seseorang sehingga menjadi satu dalam perilaku kehidupan orang tersebut. Sehingga disimpulkan pendidikan karakter itu tidak hanya sekedar mengajarkan mana yang benar dan mana yang salah. Melainkan, pendidikan karakter adalah usaha menanamkan kebiasaan-kebiasaan yang baik sehingga peserta didik dapat bersikap dan bertindak berdasarkan nilainilai yang telah menjadi kepribadiannya.

\subsubsection{Keterampilan Sosial}

Dalam penelitian ini penulis juga menggunakan angket keterampilan sosial kepada masing-masing siswa. Angket keterampilan sosial terdiri dari 26 butir yang terdiri dari 13 pernyataan positif dan 13 negatif. Angket keterampilan sosial berisi pernyataan-pernyataan yang dikembangkan dari indikator-indikator yang telah ditentukan antara keadaan anak dan interaksi anak dengan lingkungannya.

Pada hasil penelitian dan analisis data keterampilan sosial diperoleh dari 30 siswa yang memiliki persentase $100 \%$ dengan kriteria cukup baik. Hasil perhitungan diperoleh rata-rata total 3,11 yang berada pada kategori cukup baik.

Hal ini sesuai dengan pendapat Muijs dan Reynolds (2008), bahwa keterampilan sosial merupakan tujuan utama dalam pendidikan yang bertujuan meningkatkan kesiapan sekolah seperti kemampuan untuk menghormati orang lain, untuk bekerja sama secara kooperatif, mampu mengekspresikan emosi dan perasaan dengan cara baik, mau mendengarkan orang lain, untuk mengikuti aturan dan prosedur dan mau bekerja secara mandiri. Hal-hal tersebut merupakan bagian dari pendidikan karakter yang harus ada didalam diri seseorang.

\subsubsection{Pengaruh Integrasi Pendidikan} Karakter Terhadap Keterampilan Sosial

Dari analisis pendidikan karakter terhadap keterampilan sosial siswa setelah membagikan angket ditinjau dari hasil perhitungan regresi linier sederhana yang menunjukkan bahwa keterampilan sosial siswa kelas V SD Negeri 3 Kabupaten Sorong dapat dipengaruhi oleh pendidikan karakter dengan signifikansi $F_{\text {hitung }}$ sebesar 24,917 dimana lebih besar dibanding $F_{\text {tabel }}$ yaitu 4,20 
pada taraf $5 \%$. Karena $\mathrm{F}_{\text {hitung }}>\mathrm{F}_{\text {tabel }}$ maka $\mathrm{H}_{1}$ diterima. Persamaan regresi ditunjukkan oleh persamaan $\mathrm{Y}=48,57+$ $0,399 X$ dengan nilai koefisien intersap ( $\alpha$ ) 48,57 dan nilai koefisien intersap persamaan regresi (b) sebesar 0,399. Nilai $r$ sebesar 0,216 dan $r$ square sebesar 0,470 .

Hasil tersebut menunjukkan bahwa terdapat pengaruh positif dan sangat signifikan antara pendidikan karakter terhadap keterampilan sosial siswa, 47,0 \% variabel keterampilan sosial (Y) ditentukan oleh variabel pendidikan karakter $(\mathrm{X})$. Karena $\mathrm{r}_{\text {hitung }}>$ $r_{\text {tabel }}$ yaitu $0,686>r_{\text {tabel }}$, dimana $r_{\text {tabel }}$ $0,361(0,05)$ maka pendidikan karakter dan keterampilan sosial memiliki korelasi yang kuat.

Pendidikan tidak hanya untuk mentransfer pengetahuan kognitif semata, melainkan juga mengenai upaya pembentukan masyarakat yang berkarakter. Hal tersebut dapat ditanamkan pada siswa untuk mewujudkan pribadi yang memiliki keterampilan sosial dan mampu berkomunikasi dengan baik. Dalam membangun pendidikan karakter siswa diharapkan mampu mengembangkan keterampilan sosial agar siswa dapat berkomunikasi dengan baik (Anggraini, Hanurawan, \& Hadi, 2017).

\section{KESIMPULAN}

Diperoleh hasil perhitungan uji reliabilitas terhadap instrumen angket pendidikan karakter diperoleh hasil Cronbach's Alpha sebesar 0,703. Berdasarkan perhitungan uji reliabilitas terhadap instrumen angket keterampilan sosial diperoleh hasil Cronbach's Alpha sebesar 0,698. Berdasarkan uji normalitas menunjukkan nilai Asymp. Sig (2-tailed) > 0,05 maka distribusi data normal sehingga diperoleh data dari pendidikan karakter Asymp. Sig (2-tailed) 0,071>0,05 dan data dari keterampilan sosial Asymp. Sig (2- tailed) $0,198>0,05$ maka diperoleh keputusan data normal.

Berdasarkan hasil analisis regresi linier sederhana yang telah diteliti untuk mengetahui pengaruh antara pendidikan karakter terhadap keterampilan sosial siswa menunjukkan pengaruh yang disignifikan dilihat dari nilai koefisien korelasi sebesar $68,6 \%$. Hal ini menunjukkan bahwa variabel keterampilan sosial $\mathrm{Y}$ dipengaruhi sebesar $68,6 \%$ oleh pendidikan karakter $\mathrm{X}$ sedangkan sisanya $(100 \%-68,6 \%=31,4 \%)$ dipengaruhi faktor-faktor yang lain.

Dari perhitungan $F_{\text {tabel }}$ maka dapat diperoleh $\mathrm{F}_{\text {tabel }}$ sebesar 4,20 pada taraf $5 \%$. $\mathrm{H}_{0}$ ditolak apabila $\mathrm{F}_{\text {hitung }}>\mathrm{F}_{\text {tabel. }}$. Karena $\mathrm{F}_{\text {hitung }}$ $=24,917$ dan lebih besar dari $F_{\text {tabel }} 4,20$ maka $\mathrm{H}_{0}$ ditolak dan $\mathrm{H}_{1}$ diterima. Sehingga dapat disimpulkan bahwa terdapat pengaruh yang signifikan antara pendidikan karakter terhadap keterampilan sosial siswa. Dengan demikian, hipotesis yang diajukan dalam penelitian ini adalah pengaruh integrasi pendidikan karakter dalam pembelajaran IPS terhadap keterampilan sosial siswa kelas V di SD Negeri 3 Kabupaten Sorong dapat diterima.

\section{DAFTAR RUJUKAN}

Afandi, R. (2011). Integrasi Pendidikan Karakter Dalam Pembelajaran IPS Di Sekolah Dasar. Pedagogia: Jurnal Pendidikan.https://doi.org/10.21070/ped agogia.v1i1.32

Almerico, G. M. (2014). Building character through literacy with children' $\mathrm{s}$ literature. Research in Higher Education Journal.

Amtorunajah, M. S. M. (2015). Peningkatan Keterampilan Sosial Siswa Dalam Pembelajaran Ips Melalui Outdoor Activity Di Smp Negeri 1 Kaligondang Kabupaten Purbalingga. 2(1), 1-11.

Anggraini, F. L., Hanurawan, F., \& Hadi, S. (2017). Membangun Keterampilan Sosial Sebagai Pendidikan Karakter Pada Kegiatan Ekstrakurikuler. 975982.

Anshor, S. (2014). Kontribusi Ilmu 
Pengetahuan Sosial Dalam Pendidikan Karakter. III(2), 59-76.

Arikunto, S. (2010). Research procedure a practical approach. Jakarta: PT Rineka Reserved.

Barat, K. A. (2018). Peningkatan Keterampilan Sosial 79. 5(1), 79-90.

Berkowitz, M. W., \& Hoppe, M. A. (2009). Character education and gifted children. High Ability Studies. https://doi.org/10.1080/1359813090335 8493

Kesuma, T. (2012). Permana. Pendidikan Karakter: Kajian Teori dan Praktik di Sekolah. Bandung: Remaja Rosdakarya. Muijs, D., Reynolds, D., Soetjipto, H. P., \& Soetjipto, S. M. (2008). Effective teaching: teori dan aplikasi. Pustaka Pelajar.

Putra, A. N. S. (2015). Upaya meningkatkan Hasil Belajar Ipsmenggunakan Metode Peta Konsep Bagi Siswa Kelas Iii Sd Nminomartani 1 Tahun Pelajaran.

Ramdani, Z., \& Zamroni, D. A. N. (2014). Integrasi Pendidikan Karakter dalam Pembelajaran IPS di MTsN Model
Selong Lombok Timur. 11(1), 104-117.

Rasyid, H. A., \& Hasyim, M. W. (2016). Implementasi Pendidikan Karakter dalam Pembelajaran IPS di Madrasah Aliyah.

Setiawan, D. (2013). The role of character education in developing moral intelegence. 53-63.

Sugiyono, P. D. (2013). Metode Penelitian Manajemen. Bandung: Alfabeta, CV.

Suharsimi, A. (2013). Prosedur Penelitian, Jakarta: PT. Rineka Cipta, 201.

Tyas Martika Anggriana, Asroful Kadafi, R. P. T. (2017). Peran konselor dalam meningkatkan keterampilan sosial siswa difabel. 146-151.

Widyastuti, D. T. . 201. (2011). Keterampilan Sosial Siswa Sekolah Dasar ( Studi Pada Sdn 5 Bangsri Jepara ).

Yudiastuti, R. (2015). Peningkatan Keterampilan Sosial Melalui Bermain Peran Pada Kelompok B TK Pertiwi Ngablak Kecamatan Srumbung. 